\title{
Basal cortisol levels and the relationship with clinical symptoms in multiple sclerosis: a systematic review
}

\author{
Níveis de cortisol basal e a relação com sintomas clínicos na esclerose múltipla: uma \\ revisão sistemática \\ Gabriela Magalhães Pereiraํ, Nayron Medeiros Soares², Andreo Rysdyk de Souza', Jefferson Becker ${ }^{3}$, \\ Alessandro Finkelsztejn ${ }^{4}$, Rosa Maria Martins de Almeida ${ }^{5}$
}

\begin{abstract}
Multiple sclerosis (MS) is a demyelinating, progressive and neurodegenerative disease. A disturbance on the hypothalamic-pituitaryadrenal axis can be observed in patients with MS, showing altered cortisol levels. We aimed to identify basal cortisol levels and verify the relationship with clinical symptoms in patients with MS. A systematic search was conducted in the databases: Pubmed, Web of Science and SCOPUS. Both higher and lower cortisol levels were associated with MS. Higher cortisol levels were associated with depression and anxiety, while lower levels were associated with depression, fatigue and urinary dysfunction. Higher cortisol levels may be associated with the progression and severity of MS.
\end{abstract}

Keywords: Multiple sclerosis; hydrocortisone; pituitary-adrenal system; neurologic manifestations; general symptoms.

RESUMO

A esclerose múltipla (EM) é uma doença desmielinizante, progressiva e neurodegenerativa. Um distúrbio no eixo hipotálamo-hipófiseadrenal pode ser observado em pacientes com EM, mostrando níveis alterados de cortisol. Nosso objetivo foi identificar os níveis basais de cortisol e verificar a relação com os sintomas clínicos em pacientes com EM. Uma busca sistemática foi realizada nas bases de dados: Pubmed, Web of Science e SCOPUS. Ambos os níveis de cortisol elevado e baixo foram associados com a EM. Niveis mais elevados de cortisol foram associados à depressão e ansiedade, enquanto níveis mais baixos foram associados à depressão, fadiga e disfunção urinária. Níveis altos de cortisol podem estar associados à progressão e gravidade da EM.

Palavras-chave: Esclerose múltipla; hidrocortisona; sistema hipófise-suprarrenal; manifestações neurológicas; sintomas gerais.

Multiple sclerosis (MS) is a progressive and inflammatory neurodegenerative disease, characterized by demyelinating lesions and atrophy, in the central nervous system $(\mathrm{CNS})^{1,2,3}$. It affects $1 / 1,000$ people in the western world and leads to chronic disability in young adults ranging between 20 and 40 years old ${ }^{4}$. Multiple sclerosis presents an unpredictable and often progressive course, with many neurological symptoms ${ }^{5}$, which include sensory disorders ${ }^{6}$, visual problems ${ }^{7}$, fatigue ${ }^{8}$, alterations in balance ${ }^{9}$, dysfunction of the lower urinary tract $^{10}$, limitations in walking ${ }^{11}$ and cognitive dysfunction ${ }^{12}$.
The etiology of MS is considered multifactorial and involves genetic and environmental mechanisms, which affect the immunological response ${ }^{13}$. Although the origin is still unknown, autoimmune mechanisms are considered central triggers of $\mathrm{MS}^{14}$. A widely-accepted model considers MS to be an autoimmune chronic inflammation, mediated by T-cells and macrophages infiltrating the CNS through the peripheral immunological system, which is involved in myelin sheath destruction along with microglia ${ }^{10,15}$. Nowadays B-cells are getting a great deal of attention as well.

\footnotetext{
${ }^{1}$ Universidade Federal do Rio Grande do Sul, Instituto de Ciências Básicas da Saúde, Laboratório de Psicologia Experimental, Neurociências e Comportamento, Porto Alegre RS, Brasil;

2Universidade Federal do Rio Grande do Sul, Faculdade de Medicina, Laboratório de Psicologia Experimental, Neurociências e Comportamento, Porto Alegre RS, Brasil;

${ }^{3}$ Pontifícia Universidade Católica do Rio Grande do Sul, Hospital São Lucas, Serviço de Neurologia, Porto Alegre RS, Brasil;

4Hospital de Clínicas de Porto Alegre, Ambulatório de Esclerose Múltipla, Porto Alegre RS, Brasil;

${ }^{5}$ Universidade Federal do Rio Grande do Sul, Instituto de Psicologia, Laboratório de Psicologia Experimental, Neurociências e Comportamento, Porto Alegre RS, Brasil. Correspondence: Rosa Maria Martins de Almeida; Instituto de Ciências Básicas da Saúde da UFRGS; Rua Sarmento Leite, 500; 90050 -170 Porto Alegre RS, Brasil; E-mail: rosa.almeida@ufrgs.br
}

Conflict of interest: There is no conflict of interest to declare.

Received 15 April 2018; Received in final form 31 May 2018; Accepted 6 June 2018. 
It has been demonstrated that alterations in the neuroendocrine system may also be involved in immune suppression or activation, increasing the vulnerability and severity of autoimmune diseases such as $\mathrm{MS}^{4,16,17}$. In this context, several studies have indicated that there is a role of the hypothalamic-pituitary-adrenal (HPA) axis in the control of MS progression $^{18}$. In physiological conditions, the HPA axis releases glucocorticoids able to mediate the expression of inflammatory genes of cytokines, action of monocytes and macrophages, and adhesion and migration molecules, which have immunomodulatory effects ${ }^{19,20}$. In patients with MS, activation of the HPA axis appears to be dysregulated, and chronic hyperactivity occurs in about $50 \%$ of the patients ${ }^{14,18,21,22}$. The reactivity of the HPA axis has been correlated with MS progression and global increase in the activation of the neurodegenerative process ${ }^{21,23,24}$.

Cortisol is an end-product glucocorticoid of the HPA axis in humans, considered to be the stress hormone and a powerful natural immunosuppressant, involved in regulatory functions such as in glucose metabolism, insulin release, arterial pressure, immune and inflammatory responses ${ }^{4,25}$. In MS, as a consequence of the disrupted HPA axis, cortisol levels become altered. In patients with MS, the cortisol response after intravenous administration of corticotrophin-releasing hormone is higher, when compared with healthy adult subjects ${ }^{26,27,28}$. This increase of the cortisol response was associated both positively ${ }^{29}$, and negatively $^{30}$, with the number of acute lesions due to central neuroinflammation in MS.

In several studies, higher levels of basal cortisol were observed in the cerebrospinal fluid (CSF) and blood, as well as an increase in the cortisol awakening response measured in saliva ${ }^{5,25,30,31,32,33}$. As well, evidence in postmortem humans showed that higher levels of cortisol in the CSF are neuroprotective while lower levels are related to a higher number of lesions ${ }^{30}$.

Physiologically, cortisol release levels and the activated cerebral regions depend on the type of stress factor, where motor stress has been associated with brainstem activation while psychological stress has been associated with limbic regions ${ }^{34}$. In MS, some studies have investigated the relationship between cortisol levels and symptoms that arise during the course of the disease; however, there is still no consensus about the role of cortisol as a cause or consequence of the symptoms. Current evidence is directed, mainly, to the relationship of cortisol with fatigue and depression, which are the most common symptoms in $\mathrm{MS}^{35,36}$.

In affective symptoms, such as anxiety and depression, significant correlations are found with higher levels of cortisol, especially in patients suffering from relapsing-remitting multiple sclerosis (RRMS) 5,29,37. Furthermore, studies have shown that cortisol is correlated with fatigue and might have an important role in RRMS ${ }^{25,38}$. Nevertheless, contradictory results have also been observed, where MS patients with depression and chronic fatigue showed cortisol levels with no increase or significant correlations ${ }^{39,40,41}$.

Even though several investigations have considered the role of the HPA axis in MS, there is still little consensus about the cortisol levels and their role in MS pathophysiology. In this study, we aimed to investigate basal cortisol levels in MS and the methods of cortisol evaluation, though a systematic review. Moreover, we intended to verify whether cortisol levels were related to clinical symptoms observed in multiple sclerosis.

\section{METHODS}

The systematic review was performed on the results of the database searches from January to March in 2018, which were conducted according to PRISMA guidelines ${ }^{42}$. The articles were selected from three databases: PubMed, Web of Science and SCOPUS. To find representative articles, the following keywords were input: [multiple sclerosis AND cortisol]; [multiple sclerosis AND cortisol AND progression]; [multiple sclerosis AND stress AND cortisol]; [multiple sclerosis AND cortisol AND progression AND stress].

The selected articles in this review were assessed independently by two evaluators and met the following criteria: 1) the sample comprised only humans (from 18 years of age); 2) the articles were published between 2006 and 2017; 3) patients had been affected only by MS, with no neurological diseases from other etiologies; 4) cortisol had been assessed from urine, blood, CSF, saliva or hair; 5) there was an assessment of any physical, behavioral and/or cognitive symptom; 6) the full text of the article was available in the database; 7) the full article was in English. Articles were excluded from the sample if: 1) they were review articles, book chapters and abstracts published in journals; 2) they used pharmacological, physical or psychological stimulation as a stressing agent to observe the HPA axis function. Only articles that fulfilled all the requirements were included in this review.

In the initial assessment, only the abstracts of the articles were read. If the data were not enough, the evaluators assessed the methods and results of the articles. Accepted articles that met all the inclusion criteria were read and analyzed comprehensively.

Analysis of the articles was made qualitatively, according to the method of assessment of cortisol and the division of study groups. After analyzing the articles, results were placed in a table with the following information: authors and year of publication, study goals, sample number and groupings, mean age, main results (Table 1). Bias risk was assessed in every article according to the following criteria: sample randomization; cortisol storage duration, temperature, method; assessment kit (Table 2). 


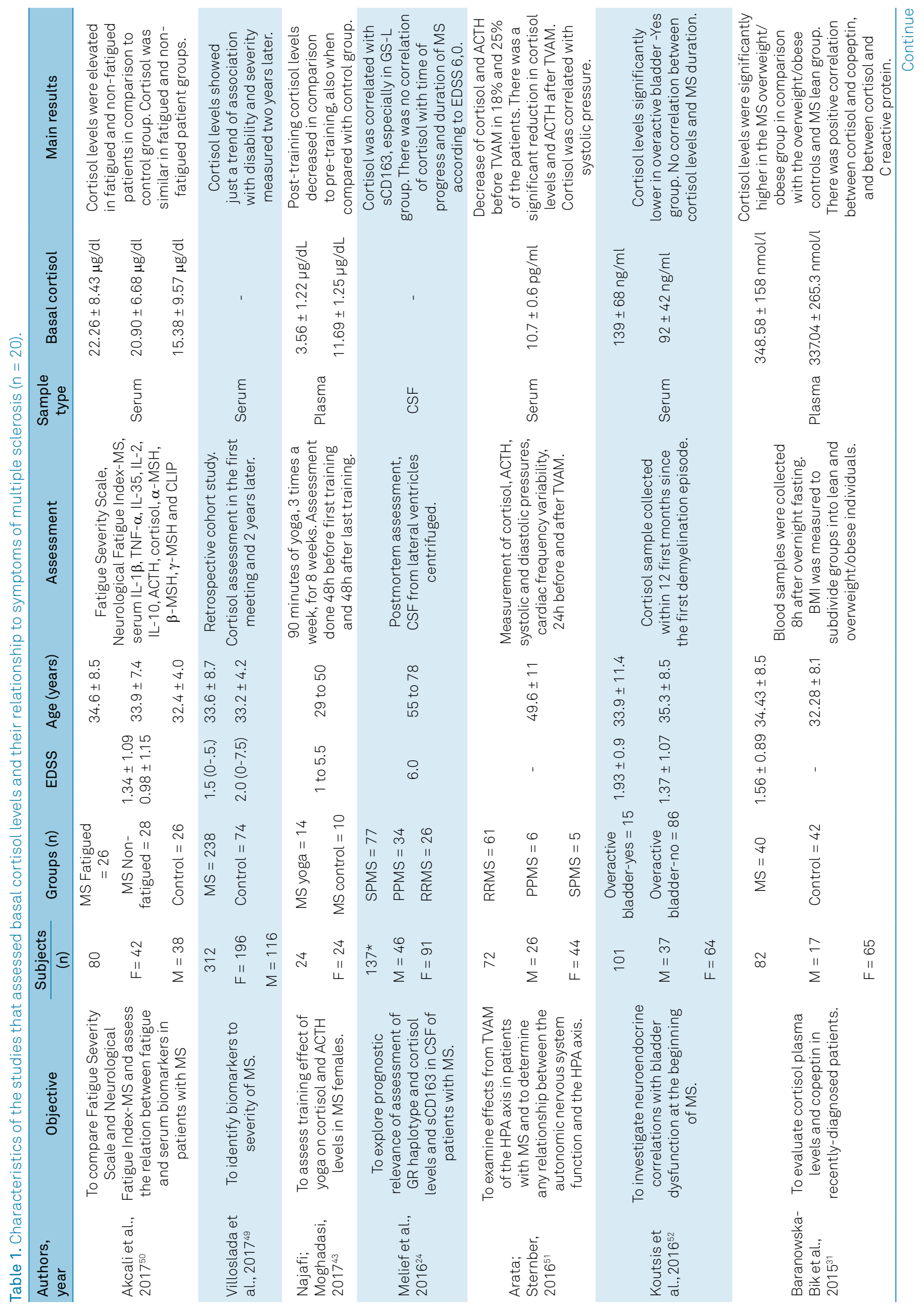




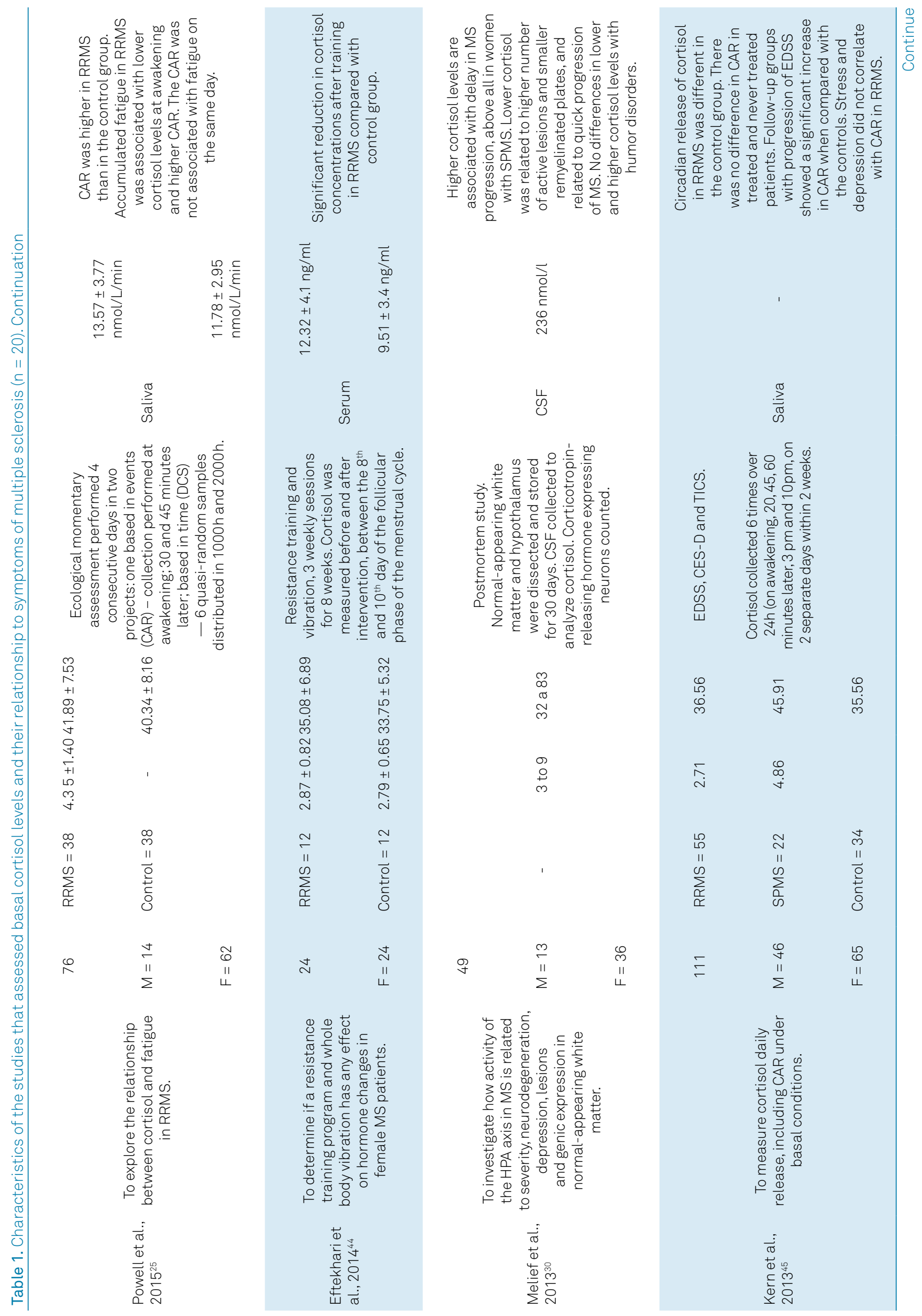




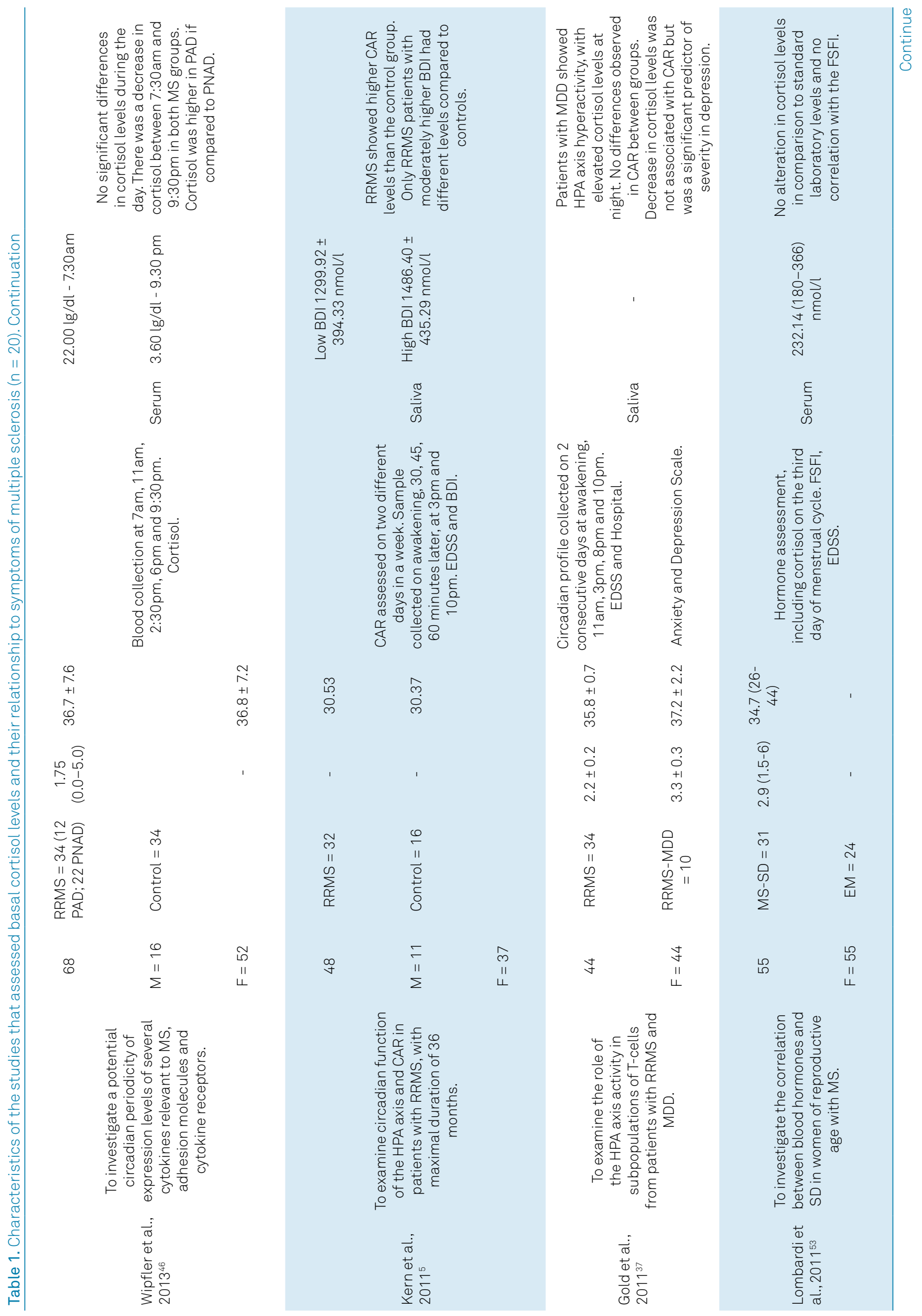




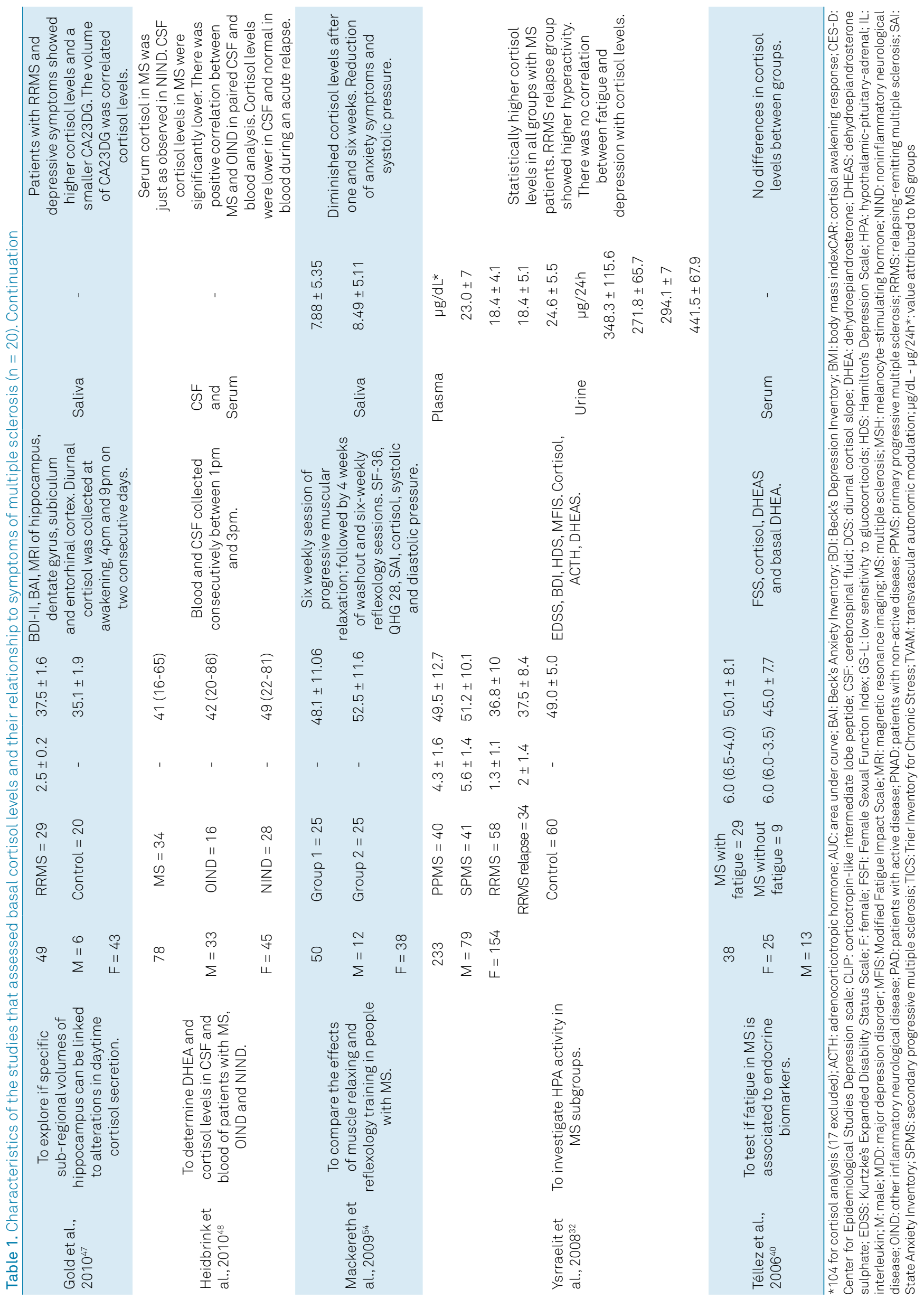


Table 2. Analysis of methodological quality of bias risk in the selected articles ( $n=20)$.

\begin{tabular}{|c|c|c|c|c|c|}
\hline $\begin{array}{l}\text { Study, } \\
\text { Year }\end{array}$ & $\begin{array}{l}\text { Sample } \\
\text { randomization }\end{array}$ & Pharmacologic Therapy & $\begin{array}{c}\text { Cortisol } \\
\text { storage time }\end{array}$ & $\begin{array}{l}\text { Cortisol storage } \\
\text { temperature }\end{array}$ & Assessment kit \\
\hline $\begin{array}{l}\text { Akcali et al., } \\
2017^{50}\end{array}$ & No & $\begin{array}{l}\text { Without DMT or corticosteroids - } \\
\qquad 3 \text { months }\end{array}$ & - & $-80^{\circ} \mathrm{C}$ & $\begin{array}{l}\text { Electrochemiluminescence } \\
\text { Cobas }^{\circledR} 8000 \text { modular system }\end{array}$ \\
\hline $\begin{array}{l}\text { Villoslada et al. } \\
2017^{49}\end{array}$ & Yes & DMT & - & $-80^{\circ} \mathrm{C}$ & $\begin{array}{l}\text { Ultra-high pressure liquid } \\
\text { chromatography-MS }\end{array}$ \\
\hline $\begin{array}{l}\text { Najafi; } \\
\text { Moghadasi, } \\
2017^{43}\end{array}$ & Yes & $\begin{array}{l}\text { Without corticosteroids - } \\
3 \text { months }\end{array}$ & - & - & Radioimmunoassay \\
\hline $\begin{array}{l}\text { Melief et al., } \\
2016^{24}\end{array}$ & No & - & - & $-80^{\circ} \mathrm{C}$ & Radioimmunoassay \\
\hline $\begin{array}{l}\text { Koutsis et al., } \\
2016^{52}\end{array}$ & No & Drug-free & 3 months & $-30^{\circ} \mathrm{C}$ & Radioimmunoassay \\
\hline $\begin{array}{l}\text { Baranowska- } \\
\text { Bik et al., } \\
2015^{31}\end{array}$ & No & Naive & - & $-70^{\circ} \mathrm{C}$ & Radioimmunoassay \\
\hline $\begin{array}{l}\text { Powell et al., } \\
2015^{25}\end{array}$ & No & $\begin{array}{l}\text { Without corticosteroids - } \\
3 \text { months }\end{array}$ & - & $-20^{\circ} \mathrm{C}$ & $\begin{array}{l}\text { Immunoassay with } \\
\text { fluorescent detection }\end{array}$ \\
\hline
\end{tabular}

\begin{tabular}{|c|c|c|c|c|c|}
\hline $\begin{array}{l}\text { Arata; } \\
\text { Sternberg, } \\
2016^{51}\end{array}$ & No & - & - & - & Electrochemiluminescence assay \\
\hline $\begin{array}{l}\text { Melief et al., } \\
2013^{30}\end{array}$ & No & $\begin{array}{l}\text { Without corticosteroids - } \\
\qquad 8 \text { weeks }\end{array}$ & - & $-70^{\circ} \mathrm{C}$ & Radioimmunoassay \\
\hline $\begin{array}{l}\text { Kern et al., } \\
2013^{45}\end{array}$ & No & Naive and DMT & - & $-20^{\circ} \mathrm{C}$ & Immunoluminescence assay \\
\hline $\begin{array}{l}\text { Wipfler et al., } \\
2013^{46}\end{array}$ & No & $\begin{array}{l}\text { Without immunomodulatory/ } \\
\text { immunosuppressive therapy } \\
\text { ( } 3 / 6 \text { months) }\end{array}$ & - & - & ELISA enzymatic immunoassay \\
\hline $\begin{array}{l}\text { Kern et al., } \\
2011^{5}\end{array}$ & No & $\begin{array}{l}\text { Within DMT/without } \\
\text { glucocorticoids }-4 \text { weeks }\end{array}$ & - & $-20^{\circ} \mathrm{C}$ & Immunoluminescence assay \\
\hline $\begin{array}{l}\text { Gold et al., } \\
2011^{37}\end{array}$ & No & $\begin{array}{l}\text { Without steroid/ } \\
\text { immunosuppressive } \\
\text { treatment - } 4 \text { weeks }\end{array}$ & - & - & Radioimmunoassay \\
\hline $\begin{array}{l}\text { Lombardi et al., } \\
2011^{53}\end{array}$ & No & $\begin{array}{l}\text { Without corticosteroids - } \\
\qquad 2 \text { months }\end{array}$ & - & - & Enzymatic immunoassay \\
\hline
\end{tabular}

\begin{tabular}{|c|c|c|c|c|c|}
\hline $\begin{array}{l}\text { Gold et al., } \\
2010^{47}\end{array}$ & No & Without steroids - 3 months & - & $-20^{\circ} \mathrm{C}$ & Competitive bonding assay \\
\hline $\begin{array}{l}\text { Heidbrink et al., } \\
2010^{48}\end{array}$ & No & $\begin{array}{l}\text { Without corticosteroids, } \\
\text { immunosuppressants or } \\
\text { immunomodulators (3 months) }\end{array}$ & - & $-80^{\circ} \mathrm{C}$ & Immunoluminescent assay \\
\hline
\end{tabular}

$\begin{array}{lcc}\begin{array}{l}\text { Mackereth } \\ \text { et al., 200954 }\end{array} & \text { Yes } & - \\ \begin{array}{l}\text { Ysrraelit et al., } \\ 2008^{32}\end{array} & \text { No } & \begin{array}{c}\text { No steroids, } \\ \text { immunosuppressants or } \\ \text { immunomodulators }(>6 \text { mont }\end{array} \\ \begin{array}{l}\text { Eftekhari et al., } \\ 2014^{44}\end{array} & \text { Yes } & \begin{array}{c}\text { Without corticosteroids } \\ \text { (6 months) }\end{array}\end{array}$

\begin{tabular}{lccc} 
& No steroids (6 months) & $-80^{\circ} \mathrm{C}$ & $\begin{array}{c}\text { Immunoassay with } \\
\text { chemillez et al., }\end{array}$ \\
$2006^{40}$ & $\begin{array}{c}\text { 6-methylprednisolone } \\
\text { (only 2 patients) }\end{array}$ & - \\
\hline C. Celsius: DMT: disease modifying treatment.
\end{tabular}

C: Celsius; DMT: disease modifying treatment. 


\section{RESULTS}

In the initial screening, using the above-mentioned keywords, 87 articles were found in PubMed, 149 in Web of Science and 103 in SCOPUS, 339 articles in total. Out of these, 208 articles were excluded as they were in more than one database and 97 articles did not meet the criteria, leaving 34 articles eligible for assessment. The final process of selection resulted in 20 articles being included. All the articles assessed basal cortisol levels in patients with MS, but only 13 studied the relationship of cortisol with any symptom present in the course of MS. The selection process is shown in Figure 1.

\section{Assessment of basal cortisol levels in MS}

A total of 20 articles investigated cortisol levels in basal conditions in MS (Table 1). The sample size in MS groups ranged from $24^{43,44}$ to $173^{32}$ individuals, and some studies included control groups without MS 5,25,31,32,45,46,47,48,49. According to Kurtzke's Expanded Disability Status Scale (EDSS), the severity of disease, when assessed, ranged from 1-6.5 points, in individuals from 29-65 years old. In most of the studies (14/20), the patients had not used glucocorticoids, immunomodulators or immunosuppressors for at least one month and, in only three articles, the patients either had never been subjected to pharmacological treatment or used to receive the conventional treatment.

Generally, the studies had three types of general objectives: to verify the effect of treatment, pretreatment or posttreatment on cortisol levels, excluding articles about pharmacological/psychological induction $(n=4)$; to describe the relationship between cortisol and MS symptoms $(\mathrm{n}=13)$ or another condition $(\mathrm{n}=1)$; and to observe the HPA axis profile in patients with MS $(\mathrm{n}=13)$.

The results of cortisol levels were divergent, many articles

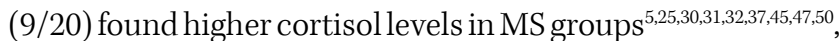
while others $(4 / 20)$ showed lower levels ${ }^{30,48,51,52}$ or did not differentiate $(3 / 20)$ from the control group or laboratory thresholds ${ }^{24,46,53}$. Some articles did not classify higher or
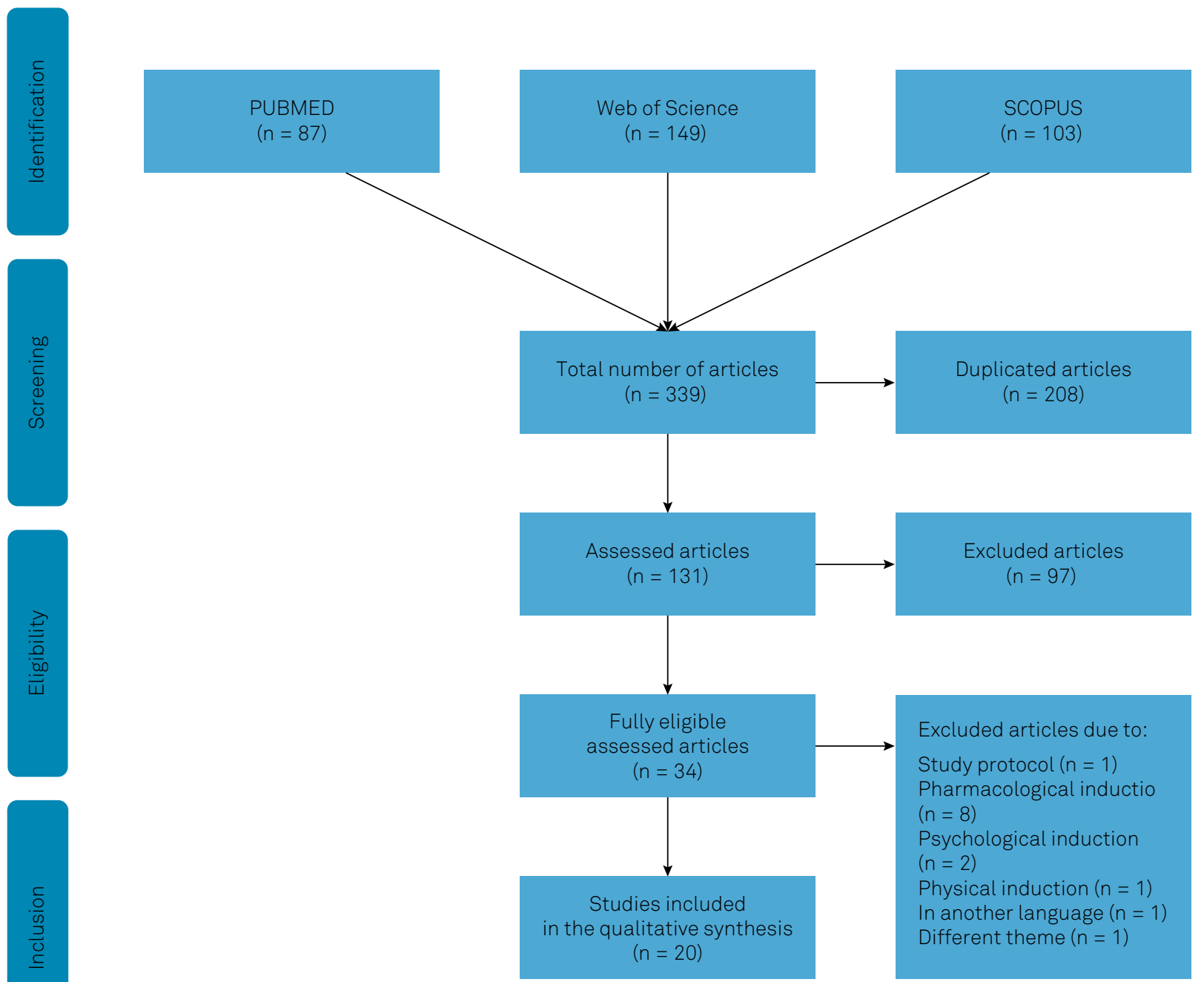

Excluded articles $(n=97)$
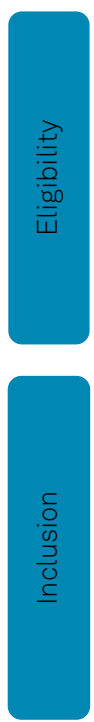

Excluded articles due to:

Study protocol $(n=1)$ Pharmacological inductio $(n=8)$

Psychological induction $(n=2)$

Physical induction $(n=1)$ In another language $(n=1)$ Different theme $(n=1)$ 
lower cortisol levels (4/20), presenting only the treatment effect ${ }^{43,44,49,54}$, where there was a reduction in levels after interventions or just the relationship with the symptom $(1 / 20)^{40}$.

Five studies did not show a significant correlation between cortisol levels with the duration, progression or severity of MS5,24,32,47,52. One study showed that the cortisol awakening response was associated with the progression of RRMS ${ }^{45}$. There was also a study in which cortisol levels showed a trend to correlation with severity progress in their results $^{49}$. In another study, low cortisol was associated with fast progression and severity of $\mathrm{MS}^{30}$.

\section{Types of cortisol samples}

Cortisol levels in the articles were assessed from blood, saliva, CSF and urine (Figure 2), while most of the studies used serum samples or blood plasma $(60 \%$; $n=12)$. Two articles performed double sampling of cortisol through plasma/urine ${ }^{32}$ and serum $/ \mathrm{CSF}^{48}$, the latter showing a significant difference between the sampling types (CSF: $p=$ 0.0256; serum: $p=0.2886$ ) in different stages of the disease. All the studies that collected saliva investigated the circadian and daytime response of cortisol. No study assessed cortisol from hair samples.

Two postmortem studies included in this review assessed cortisol from CSF and just one in vivo study performed this type of sampling. Storing temperature, if mentioned, ranged between $-30^{\circ} \mathrm{C}$ and $-80^{\circ} \mathrm{C}$ (Table 2 ). The most-used method of analysis was radioimmunoassay $(31.6 \% ; n=6)$ and the leastused methods were the competitive binding assay $(5.3 \%$; $n=$ 1 ), and the ultra-high pressure liquid chromatography with mass spectrometry $(5.3 \%, \mathrm{n}=1)$.

\section{Relationship between cortisol and MS symptoms}

A total of 13 articles verified the relationship of cortisol levels with symptoms or comorbidities present in patients with $\mathrm{MS}^{5,25,30,31,32,37,40,45,47,50,52,53,54}$. The severity of the disease ranged from 1.3-9 points on the EDSS and the age varied from

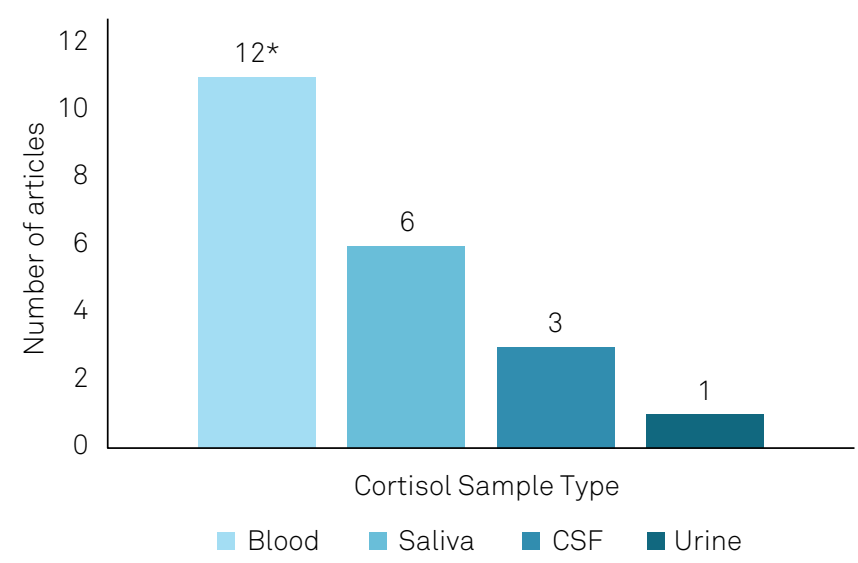

Figure 2. Distribution of articles according to cortisol sample $(n=20)$. *Includes articles with double sampling ${ }^{32,48}$.
32-82 years old. The investigated symptoms were depression $^{5,30,32,37,45,47}$, fatigue ${ }^{25,32,40,50}$, urinary dysfunction ${ }^{52}$, female sexual dysfunction ${ }^{31}$, anxiety ${ }^{54}$ and obesity ${ }^{31}$.

The most-assessed symptom was depression and three articles found hyperactivity of the HPA axis, correlating high cortisol levels with depression ${ }^{5,37,47}$. In contrast, other studies (4/20) did not find a correlation between lower ${ }^{30}$ or higher ${ }^{30,32,45}$ cortisol levels. Next, fatigue was assessed by four articles, which verified a relationship in patients with a low cortisol awakening response ${ }^{25}$, high levels of cortisol in patients with fatigue compared to controls ${ }^{50}$ or did not observe any relationship between fatigue and cortisol ${ }^{32,40}$.

One study found that there may be a reduction of anxiety symptoms associated with lower cortisol levels ${ }^{54}$. Another study did not find a correlation between cortisol and female sexual dysfunction ${ }^{53}$, however, lower cortisol levels were related to urinary symptoms in both genders ${ }^{52}$. Finally, overweight patients with MS showed a higher release of cortisol when compared with lean patients ${ }^{32}$.

\section{DISCUSSION}

This review included 20 articles, which assessed basal cortisol levels and verified their relationship with any type of symptoms and comorbidities $(n=13)$ in patients with MS. Those studies assessed cortisol through in vivo $(18 / 20$ studies) and postmortem (2/20 studies) samples. The mostcommon sample type for assessing cortisol was blood (12/20 studies). Hyperactivity of the HPA axis was observed in most studies (9/20). The most-investigated symptom was depression (6/13 studies). Among the assessed articles, only three found any correlation between cortisol and the duration and progression of MS.

The results found in the various studies in this review support the HPA axis profile in MS, through measuring released cortisol levels. Generally, in most studies, patients with MS showed higher cortisol levels, indicating hyperactivity of the HPA axis, similar to previously-found results ${ }^{26,27}$. Although this impairment can be observed in many cases, its causeand-effect relationship remains unknown. However, some hypotheses point out its role in affective disorders, such as depression $^{55}$, which arises during the course of MS. Thus, depressed patients had higher levels of serum cortisol and this hyperactivity may be related to a decreased response of negative feedback mediated by endogenous glucocorticoids ${ }^{56}$.

Alternatively, this hyperactivity of the HPA axis may be linked to the inflammatory activity that happens in active MS. During the inflammatory process, release of cytokines, such as IL-1, IL-6 and TNF $\alpha$, can perform a modulatory role of the HPA axis, increasing the cortisol release ${ }^{4}$. Alternatively, the HPA axis hypoactivity found in some studies in this review, and decrease in cortisol levels, may be related to the suppression of corticotrophin-releasing hormone neurons that 
occurs in active lesion in $\mathrm{MS}^{18}$. Furthermore, applying the experimental model of autoimmune encephalomyelitis to animal models of MS has demonstrated that the severity and progression of MS is linked to HPA hyporesponsiveness ${ }^{57,58}$.

Additionally, a postmortem study has shown that lower cortisol levels were associated with larger active lesions and fewer remyelinated plates in humans, while higher cortisol levels were associated with a lower number of active lesions and an increase in plate remyelination ${ }^{30}$. From this perspective, hyperresponsive patients showed fewer lesions highlighted by gadolinium, suggesting a neuroprotection of acute lesions $\mathrm{s}^{59}$.

Controversially, the HPA axis hyperresponsiveness in MS may be associated with atrophy in the cornu ammonis and dentate gyrus in the hippocampus ${ }^{47}$, and its relationship with symptoms found in MS 5 511,37,47. Besides this, patients with exacerbations of RRMS have been shown to have higher cortisol levels compared with healthy subjects ${ }^{45}$. As well, lower cortisol levels were found during the acute relapse than in the stable stage of $\mathrm{MS}^{48}$.

In this systematic review, many of the studies did not find any relationship between cortisol and MS duration, progression or severity; however, a remarkable number of previous studies have found a relationship between HPA dysfunction and MS progression ${ }^{18,21,29,59}$. The lower cortisol levels found in this review were correlated with the progression of MS, contradicting the fact that lower levels were correlated with more brain lesions ${ }^{30}$.

Although these studies preferentially collected blood serum or plasma, this type of sampling only accounts for acute levels of cortisol release, relative to urine, saliva and CSF samples. Moreover, blood and saliva samples provide a momentary profile, while urine samples refer to cortisol levels over a 24-hour period ${ }^{60}$. However, higher cortisol levels found in studies with CSF samples might have been influenced either by the stress generated in response to lumbar puncture or, in postmortem studies, by the response of the HPA axis to the death process ${ }^{33,48}$.

Cortisol responses found in these articles refer to acute measurements of the hormone. An alternative to minimizing the interference of stress responses generated by some factors in an ambulatory assessment might be a noninvasive gathering of hair samples. This type of sampling has been considered a reliable method of measuring levels months after exposure to cortisol and it is not influenced by acute stress. Also hair samples can be stored at room temperature ${ }^{60}$.

The difference found between the blood serum sample and the CSF in the results can be explained either by the lower activation of cortisone through $11 \beta$-hydroxysteroid dehydrogenase type 1 or by inactivation via $11 \beta$-hydroxysteroid dehydrogenase type $2^{48}$, or can be regulated by the efflux of cortisol from the brain, which provides a balance to cortisol levels in blood and CSF ${ }^{61}$. In contrast, the similarity in levels found between plasma and urine ${ }^{32}$ might occur as both sample types provide cortisol levels in the peripherals.
Articles that described assessment characteristics and sample storage did this according to instructions provided by manufacturers of the respective commercial kits. Nevertheless, many studies did not clarify the duration of storage and did not use sample randomization, which made comparison of results among the studies and validity of processing more difficult and increased the bias risk. Similarly, the choice of an accurate and systematic recruitment in case control studies needed to be obtained in the light of data of healthy individuals and patients without MS, who presented for an investigated condition, such as depression. Furthermore, results in some articles were just described as higher or lower, without ever showing mean values found in each group.

Different symptoms are found in MS and they generally tend to worsen as the disease advances. Fatigue is the most common and debilitating symptom, present in more than $80 \%$ of the patients with $\mathrm{MS}^{62}$. Although it is regarded as a residual symptom of depression ${ }^{63}$, the involvement of cortisol levels remains unclear ${ }^{25}$. The main results encountered in this review on MS did not find any relationship between cortisol and fatigue, corroborating previous evidence that did not observe an influence of cortisol on the fatigue experienced by the patients ${ }^{39}$.

Excessive cortisol in the blood has been related to mood disorders ${ }^{64}$, such as anxiety and depression. Cortisol performs a central role at the onset and during the course of major depression disorder, where higher basal cortisol levels may be found ${ }^{65}$. Patients with MS who had HPA axis hyperactivity may be susceptible to developing depression ${ }^{66}$. In fact, it has been observed that symptoms of depression may precede the onset of specific neurological symptoms during the initial process of MS; however, in spite of the involvement of several epigenetic factors, the etiology of the depression is multifactorial and varies among patients ${ }^{67}$. In this context, higher cortisol levels found in those studies in patients with MS who had anxiety and depression symptoms may have been related to a hyperresponsiveness of the HPA axis found in mood disorders. The lack of correlation with cortisol levels in some studies may have been due to the methodological design and the materials of investigation employed to classify and assess the depressive disorder.

The lower cortisol levels found in urinary dysfunction may indicate a relationship between the hormones of the HPA axis and the deficit of bladder activity inhibition ${ }^{52}$. Results on the relationship between higher cortisol levels and obesity are controversial, and may be justified by several confounding factors that influence cortisol concentration, such as the increase of ACTH release due to copeptin production or the metabolic activity due to the increase of adipose tissue ${ }^{31}$.

One of the limitations of this review is the heterogeneity of the included articles. In fact, there was wide methodological variability, including controlled and uncontrolled studies, as well as randomized and non-randomized essays. Furthermore, the low number of selected articles and the variability of the 
sample types may have distorted the interpretation and involvement of cortisol with symptoms in MS. Finally, this review did not include a cohort study that evaluated long-term cortisol in patients with MS, for further understanding of its involvement in the progression of the disease.

In conclusion, this systematic review included an overview of studies that investigated basal cortisol levels and symptoms in MS. The results found pointed to a cortisol level dysfunction and some involvement with symptoms, mainly depression, present in MS. Although there was a satisfactory number of studies and promising investigations on the subject, the results still did not present a consensus on the activity of the HPA axis and cortisol release in patients with MS. However, the majority of studies indicated higher cortisol levels associated with the progression and severity of MS.
Differences related to the type of sample were found among both peripheral and central samples, though the number of studies was not enough to clarify the validity and differences among the sample types. The divergences found were limited to lack of methodological consistency, sample size and standardization, such as, for example, the duration of the disease and type of MS, as well as the evaluation types used in some studies. Because of this, further investigations are necessary to better understand the role of cortisol in MS, such as: (1) observation of the cortisol release in peripheral and central samples; (2) verification of the role of cortisol as a trigger for relapses and several motor, cognitive and behavioral symptoms that arise with the disease; and (3) elaboration on standardized methods that control the influence of the circadian cycle on this hormone.

\section{References}

1. Altowaijri G, Fryman A, Yadav V. Dietary interventions and multiple sclerosis. Curr Neurol Neurosci Rep. 2017 Mar;17(3):28. https://doi.org/10.1007/s11910-017-0732-3

2. Lassmann $\mathrm{H}$, van Horssen J, Mahad D. Progressive multiple sclerosis: pathology and pathogenesis. Nat Rev Neurol. 2012 Nov;8(11):647-56. https://doi.org/10.1038/nrneurol.2012.168

3. Loma I, Heyman R. Multiple sclerosis: pathogenesis and treatment. Curr Neuropharmacol. 2011 Sep;9(3):409-16. https://doi.org/10.2174/157015911796557911

4. Deckx N, Lee WP, Berneman ZN, Cools N. Neuroendocrine immunoregulation in multiple sclerosis. Clin Dev Immunol. 2013;2013:705232. https://doi.org/10.1155/2013/705232

5. Kern S, Schultheiss T, Schneider H, SchrempfW, Reichmann H, Ziemssen T. Circadian cortisol, depressive symptoms and neurological impairment in early multiple sclerosis. Psychoneuroendocrinology. 2011 Nov;36(10):1505-12. https://doi.org/10.1016/j.psyneuen.2011.04.004

6. Ortiz P, Bareno J, Cabrera L, Rueda K, Rovira A. [Magnetic resonance imaging with gadolinium in the acute phase of relapses in multiple sclerosis]. Rev Neurol. 2017 Mar;64(6):241-6. Spanish.

7. Sakai RE, Feller DJ, Galetta KM, Galetta SL, Balcer LJ. Vision in multiple sclerosis: the story, structure-function correlations, and models for neuroprotection. J Neuroophthalmol. 2011 Dec;31(4):36273. https://doi.org/10.1097/WNO.0b013e318238937f

8. Pilutti LA, Greenlee TA, Motl RW, Nickrent MS, Petruzzello SJ. Effects of exercise training on fatigue in multiple sclerosis: a meta-analysis. Psychosom Med. 2013 Jul-Aug;75(6):575-80. https://doi.org/10.1097/PSY.0b013e31829b4525

9. Gunn H, Markevics S, Haas B, Marsden J, Freeman J. Systematic review: the effectiveness of interventions to reduce falls and improve balance in adults with multiple sclerosis. Arch Phys Med Rehabil. 2015 Oct;96(10):1898-912. https://doi.org/10.1016/j.apmr.2015.05.018

10. Phé V, Chartier-Kastler E, Panicker JN. Management of neurogenic bladder in patients with multiple sclerosis. Nat Rev Urol. 2016 May;13(5):275-88. https://doi.org/10.1038/nrurol.2016.53

11. Pearson M, Dieberg G, Smart N. Exercise as a therapy for improvement of walking ability in adults with multiple sclerosis: a meta-analysis. Arch Phys Med Rehabil. 2015 Jul;96(7):1339-1348.e7. https://doi.org/10.1016/j.apmr.2015.02.011

12. Coric D, Balk LJ, Verrijp M, Eijlers A, Schoonheim MM, Killestein J, et al. Cognitive impairment in patients with multiple sclerosis is associated with atrophy of the inner retinal layers. Mult Scler. 2018 Feb;24(2):158-66. https://doi.org/10.1177/1352458517694090
13. Ebers GC. Environmental factors and multiple sclerosis. Lancet Neurol. 2008 Mar;7(3):268-77. https://doi.org/10.1016/S1474-4422(08)70042-5

14. Kümpfel T, Schwan M, Weber F, Holsboer F, Trenkwalder C, Then Bergh F. Hypothalamo-pituitary-adrenal axis activity evolves differentially in untreated versus treated multiple sclerosis. Psychoneuroendocrinology. 2014 Jul;45:87-95. https://doi.org/10.1016/j.psyneuen.2014.03.012

15. Lassmann H, Brück W, Lucchinetti C. Heterogeneity of multiple sclerosis pathogenesis: implications for diagnosis and therapy. Trends Mol Med. 2001 Mar;7(3):115-21. https://doi.org/10.1016/S1471-4914(00)01909-2

16. Taub DD. Neuroendocrine interactions in the immune system. Cell Immunol. 2008 Mar-Apr;252(1-2):1-6. https://doi.org/10.1016/j.cellimm.2008.05.006

17. Eskandari F, Webster JI, Sternberg EM. Neural immune pathways and their connection to inflammatory diseases. Arthritis Res Ther. 2003;5(6):251-65. https://doi.org/10.1186/ar1002

18. Huitinga I, Erkut ZA, Beurden D, Swaab DF. Impaired hypothalamuspituitary-adrenal axis activity and more severe multiple sclerosis with hypothalamic lesions. Ann Neurol. 2004 Jan;55(1):37-45. https://doi.org/10.1002/ana.10766

19. Barnes PJ. Anti-inflammatory actions of glucocorticoids: molecular mechanisms. Clin Sci (Lond). 1998 Jun;94(6):557-72. https://doi.org/10.1042/cs0940557

20. Bellavance MA, Rivest S. The HPA: immune Axis and the immunomodulatory actions of glucocorticoids in the brain. Front Immunol. 2014 Mar;5:136. https://doi.org/10.3389/fimmu.2014.00136

21. Gold SM, Raji A, Huitinga I, Wiedemann K, Schulz KH, Heesen C. Hypothalamo-pituitary-adrenal axis activity predicts disease progression in multiple sclerosis. J Neuroimmunol. 2005 Aug;165 (1-2): 186-91. https://doi.org/10.1016/j.jneuroim.2005.04.014

22. Heesen C, Gold SM, Huitinga I, Reul JM. Stress and hypothalamic-pituitary-adrenal axis function in experimental autoimmune encephalomyelitis and multiple sclerosis - a review. Psychoneuroendocrinology. 2007 Jul;32(6):604-18. https://doi.org/10.1016/j.psyneuen.2007.05.002

23. Gold SM, Heesen C. Stress and disease progression in multiple sclerosis and its animal models. Neuroimmunomodulation. 2006;13(5-6):318-26. https://doi.org/10.1159/000104860

24. Melief J, Koper JW, Endert E, Møller HJ, Hamann J, Uitdehaag BM et al. Glucocorticoid receptor haplotypes conferring increased sensitivity (Bcll and N363S) are associated with faster progression of multiple sclerosis. J Neuroimmunol. 2016 Oct;299:84-9. https://doi.org/10.1016/j.jneuroim.2016.08.019 
25. Powell DJ, Moss-Morris R, Liossi C, Schlotz W. Circadian cortisol and fatigue severity in relapsing-remitting multiple sclerosis. Psychoneuroendocrinology. 2015 Jun;56:120-31. https://doi.org/10.1016/j.psyneuen.2015.03.010

26. Grasser A, Möller A, Backmund H, Yassouridis A, Holsboer F. Heterogeneity of hypothalamic-pituitary-adrenal system response to a combined dexamethasone-CRH test in multiple sclerosis. Exp Clin Endocrinol Diabetes. 1996;104(1):31-7. https://doi.org/10.1055/s-0029-1211419

27. Then Bergh F, Kümpfel T, Trenkwalder C, Rupprecht R, Holsboer F. Dysregulation of the hypothalamo-pituitary-adrenal axis is related to the clinical course of MS. Neurology. 1999 Sep;53(4):772-7. https://doi.org/10.1212/WNL.53.4.772

28. Heesen C, Gold SM, Raji A, Wiedemann K, Schulz KH. Cognitive impairment correlates with hypothalamo-pituitary-adrenal axis dysregulation in multiple sclerosis. Psychoneuroendocrinology. 2002 May;27(4):505-17. https://doi.org/10.1016/S0306-4530(01)00071-3

29. Fassbender K, Schmidt R, Mössner R, Kischka U, Kühnen J, Schwartz A et al. Mood disorders and dysfunction of the hypothalamicpituitary-adrenal axis in multiple sclerosis: association with cerebral inflammation. Arch Neurol. 1998 Jan;55(1):66-72. https://doi.org/10.1001/archneur.55.1.66

30. MeliefJ, Wit SJ, Eden CG, Teunissen C, Hamann J, Uitdehaag BM et al. HPA axis activity in multiple sclerosis correlates with disease severity, lesion type and gene expression in normalappearing white matter. Acta Neuropathol. 2013 Aug;126(2):237-49. https://doi.org/10.1007/s00401-013-1140-7

31. Baranowska-Bik A, Kochanowski J, Uchman D, Litwiniuk A, Kalisz $M$, Martynska L et al. Association of copeptin and cortisol in newly diagnosed multiple sclerosis patients. J Neuroimmunol. 2015 May;282:21-4. https://doi.org/10.1016/j.jneuroim.2015.03.011

32. Ysrraelit MC, Gaitán MI, Lopez AS, Correale J. Impaired hypothalamic-pituitary-adrenal axis activity in patients with multiple sclerosis. Neurology. 2008 Dec;71(24):1948-54. https://doi.org/10.1212/01.wnl.0000336918.32695.6b

33. Erkut ZA, Endert E, Huitinga I, Swaab DF. Cortisol is increased in postmortem cerebrospinal fluid of multiple sclerosis patients: relationship with cytokines and sepsis. Mult Scler. 2002 May;8(3):229-36. https://doi.org/10.1191/1352458502ms797oa

34. Thompson SB, Daly S, Le Blanche A, Abidi M, Belkhira C, Marco G. fMRI randomized study of mental and motor task performance and cortisol levels to potentiate cortisol as a new diagnostic biomarker.J Neurol Neurosci. 2016;7(2):92. https://doi.org/10.21767/2171-6625.100092

35. Schapiro R. The pathophysiology of MS-related fatigue: what is the role of wake promotion? Int J MS Care. 2002;(suppl):6-8.

36. Chiaravalloti ND, DeLuca J. Cognitive impairment in multiple sclerosis. Lancet Neurol. 2008 Dec;7(12):1139-51. https://doi.org/10.1016/S1474-4422(08)70259-X

37. Gold SM, Krüger S, Ziegler KJ, Krieger T, Schulz KH, Otte C et al. Endocrine and immune substrates of depressive symptoms and fatigue in multiple sclerosis patients with comorbid major depression. J Neurol Neurosurg Psychiatry. 2011 Jul;82(7):814-8. https://doi.org/10.1136/jnnp.2010.230029

38. Heesen C, Nawrath L, Reich C, Bauer N, Schulz KH, Gold SM. Fatigue in multiple sclerosis: an example of cytokine mediated sickness behaviour? J Neurol Neurosurg Psychiatry. 2006 Jan;77(1):34-9. https://doi.org/10.1136/jnnp.2005.065805

39. Gottschalk M, Kümpfel T, Flachenecker P, Uhr M, Trenkwalder $\mathrm{C}$, Holsboer $\mathrm{F}$ et al. Fatigue and regulation of the hypothalamopituitary-adrenal axis in multiple sclerosis. Arch Neurol. 2005 Feb;62(2):277-80. https://doi.org/10.1001/archneur.62.2.277

40. Téllez N, Comabella M, Julià E, Río J, Tintoré M, Brieva L, et al. Fatigue in progressive multiple sclerosis is associated with low levels of dehydroepiandrosterone. Mult Scler. 2006;12(4):487-94. https://doi.org/10.1191/135248505ms1322oa
41. Heesen C, Schulz KH, Fiehler J, Von der Mark U, Otte C, Jung $R$ et al. Correlates of cognitive dysfunction in multiple sclerosis. Brain Behav Immun. 2010 Oct;24(7):1148-55. https://doi.org/10.1016/j.bbi.2010.05.006

42. Liberati A, Altman DG, Tetzlaff J, Mulrow C, Gøtzsche PC, loannidis JP et al. The PRISMA statement for reporting systematic reviews and meta-analyses of studies that evaluate health care interventions: explanation and elaboration. Ann Intern Med. 2009 Aug;151(4):W65-94. https://doi.org/10.7326/0003-4819-151-4-200908180-00136

43. Najafi P, Moghadasi M. The effect of yoga training on enhancement of Adrenocorticotropic hormone (ACTH) and cortisol levels in female patients with multiple sclerosis. Complement Ther Clin Pract. 2017 Feb;26:21-5. https://doi.org/10.1016/j.ctcp.2016.11.006

44. Eftekhari E, Etemadifar M, Mostahfezian M, Zafari A. Effects of resistance training and vibration on hormonal changes in female patients with multiple sclerosis. Neurol Asia. 2014;19:63-7.

45. Kern S, Krause I, Horntrich A, Thomas K, Aderhold J, Ziemssen T. Cortisol awakening response is linked to disease course and progression in multiple sclerosis. PLoS One. 2013 Apr;8(4):e60647. https://doi.org/10.1371/journal.pone.0060647

46. Wipfler P, Heikkinen A, Harrer A, Pilz G, Kunz A, Golaszewski SM et al. Circadian rhythmicity of inflammatory serum parameters: a neglected issue in the search of biomarkers in multiple sclerosis. J Neurol. 2013 Jan;260(1):221-7. https://doi.org/10.1007/s00415-012-6622-3

47. Gold SM, Kern KC, O'Connor MF, Montag MJ, Kim A, Yoo YS et al. Smaller cornu ammonis 2-3/dentate gyrus volumes and elevated cortisol in multiple sclerosis patients with depressive symptoms. Biol Psychiatry. 2010 Sep;68(6):553-9. https://doi.org/10.1016/j.biopsych.2010.04.025

48. Heidbrink C, Häusler SF, Buttmann M, Ossadnik M, Strik HM, Keller A et al. Reduced cortisol levels in cerebrospinal fluid and differential distribution of 11 beta-hydroxysteroid dehydrogenases in multiple sclerosis: implications for lesion pathogenesis. Brain Behav Immun. 2010 Aug;24(6):975-84. https://doi.org/10.1016/j.bbi.2010.04.003

49. Villoslada P, Alonso C, Agirrezabal I, Kotelnikova E, Zubizarreta I, PulidoValdeolivas I et al. Metabolomic signatures associated with disease severity in multiple sclerosis. Neurol Neuroimmunol Neuroinflamm. 2017 Jan;4(2):e321. https://doi.org/10.1212/NXI.0000000000000321

50. Akcali A, Zengin F, Aksoy SN, Zengin O. Fatigue in Multiple Sclerosis: is it related to cytokines and hypothalamic-pituitaryadrenal axis? Mult Scler Relat Disord. 2017 Jul;15:37-41. https://doi.org/10.1016/j.msard.2017.03.004

51. Arata M, Sternberg Z. Neuroendocrine responses to transvascular autonomic modulation: a modified balloon angioplasty in multiple sclerosis patients. Horm Metab Res. 2016 Feb;48(2):123-9. https://doi.org/10.1055/s-0035-1547235

52. Koutsis G, Evangelopoulos ME, Sfagos C, Markianos M. Neurochemical and neuroendocrine correlates of overactive bladder at first demyelinating episode. Neurourol Urodyn. 2016 Nov;35(8):955-8. https://doi.org/10.1002/nau.22834

53. Lombardi G, Celso M, Bartelli M, Cilotti A, Del Popolo G. Female sexual dysfunction and hormonal status in multiple sclerosis patients.J Sex Med. 2011 Apr;8(4):1138-46. https://doi.org/10.1111/j.1743-6109.2010.02161.x

54. Mackereth PA, Booth K, Hillier VF, Caress AL. Reflexology and progressive muscle relaxation training for people with multiple sclerosis: a crossover trial. Complement Ther Clin Pract. 2009 Feb;15(1):14-21. https://doi.org/10.1016/j.ctcp.2008.07.002

55. Lobentanz IS, Asenbaum S, Vass K, Sauter C, Klösch G, Kollegger $\mathrm{H}$ et al. Factors influencing quality of life in multiple sclerosis patients: disability, depressive mood, fatigue and sleep quality. Acta Neurol Scand. $2004 \mathrm{Jul} ; 110(1): 6-13$. https://doi.org/10.1111/j.1600-0404.2004.00257.x

56. Pariante CM, Lightman SL. The HPA axis in major depression: classical theories and new developments. Trends Neurosci. 2008 Sep;31(9):464-8. https://doi.org/10.1016/j.tins.2008.06.006 
57. Harbuz MS, Leonard JP, Lightman SL, Cuzner ML. Changes in hypothalamic corticotrophin-releasing factor and anterior pituitary pro-opiomelanocortin mRNA during the course of experimental allergic encephalomyelitis. J Neuroimmunol. 1993 Jun;45(1-2):127-32. https://doi.org/10.1016/0165-5728(93)90172-U

58. Stefferl A, Storch MK, Linington C, Stadelmann C, Lassmann H, Pohl T et al. Disease progression in chronic relapsing experimental allergic encephalomyelitis is associated with reduced inflammationdriven production of corticosterone. Endocrinology. 2001 Aug;142(8):3616-24. https://doi.org/10.1210/endo.142.8.8292

59. Schumann EM, Kümpfel T, Then Bergh F, Trenkwalder C, Holsboer F, Auer DP. Activity of the hypothalamic-pituitary-adrenal axis in multiple sclerosis: correlations with gadolinium-enhancing lesions and ventricular volume. Ann Neurol. 2002 Jun;51(6):763-7.

60. Sauvé B, Koren G, Walsh G, Tokmakejian S, Van Uum SH. Measurement of cortisol in human hair as a biomarker of systemic exposure. Clin Invest Med. 2007;30(5):E183-91. https://doi.org/10.25011/cim.v30i5.2894

61. Uhr M, Holsboer F, Müller MB. Penetration of endogenous steroid hormones corticosterone, cortisol, aldosterone and progesterone into the brain is enhanced in mice deficient for both mdr1a and mdr1b P-glycoproteins. J Neuroendocrinol. 2002 Sep;14(9):753-9. https://doi.org/10.1046/j.1365-2826.2002.00836.x
62. Minden SL, Frankel D, Hadden L, Perloffp J, Srinath KP, Hoaglin DC. The Sonya Slifka longitudinal multiple sclerosis study: methods and sample characteristics. Mult Scler. 2006 Feb;12(1):24-38. https://doi.org/10.1191/135248506ms1262oa

63. Targum SD, Fava M. Fatigue as a residual symptom of depression. Innov Clin Neurosci. 2011 Oct;8(10):40-3.

64. Asnis GM, Sachar EJ, Halbreich U, Nathan RS, Ostrow L, Halpern FS. Cortisol secretion and dexamethasone response in depression. Am J Psychiatry. 1981 Sep;138(9):1218-21. https://doi.org/10.1176/ajp.138.9.1218

65. Herbert J. Cortisol and depression: three questions for psychiatry. Psychol Med. 2013 Mar;43(3):449-69. https://doi.org/10.1017/S0033291712000955

66. Pucak ML, Carroll KA, Kerr DA, Kaplin Al. Neuropsychiatric manifestations of depression in multiple sclerosis: neuroinflammatory, neuroendocrine, and neurotrophic mechanisms in the pathogenesis of immune-mediated depression. Dialogues Clin Neurosci. 2007:9(2):125-39.

67. Vattakatuchery JJ, Rickards H, Cavanna AE. Pathogenic mechanisms of depression in multiple sclerosis.J Neuropsychiatry Clin Neurosci. 2011;23(3):261-76. https://doi.org/10.1176/jnp.23.3.jnp261 